\title{
Long-term dietary supplementation with natural honey does not predispose growing male rats to metabolic syndrome
}

\author{
Abdulwahid Ajibola ${ }^{1,2^{*}}$, Joseph P Chamunorwa ${ }^{3}$, Kennedy H Erlwanger ${ }^{2}$ \\ From Metabolism, diet and disease \\ Washington, DC, USA. 29-31 May 2012
}

\section{Background}

Metabolic syndrome (MetS) is a condition characterized by abdominal obesity, hyperglycaemia, hypertension and dyslipidaemia, and thus increased susceptibility to diabetes, kidney and heart diseases [1]. The modern human diet contains refined sugars mainly fructose, which is culpable in the global incidence and prevalence of MetS in adults and children [2,3]. We investigated the effects of two dietary sources of fructose, natural honey $(\mathrm{NH})$ and golden syrup (GS) on metabolism in growing animal models (Sprague Dawley rats) fed from neonatal age.

\section{Methodology}

Thirty suckling (7-day old male and female) rats were fed either NH or GS at low (10 $\mathrm{ml} \mathrm{kg}^{-1}$ b.wt) or high $\left(20 \mathrm{ml} \mathrm{kg}^{-1}\right.$ b.wt) dose daily via stomach tube for 14 days, while control group was gavaged with distilled water. The rats divided into five groups $(n=6)$ nursed freely between gavages. On weaning, $\mathrm{NH}$ or GS was mixed with rat chow as low (20\%) or high, $50 \%$ (volume/weight, $\mathrm{v} / \mathrm{m})$, while $20 \%(\mathrm{v} / \mathrm{w})$ tap water was added to the control diet. The rats were subjected to an oral glucose tolerance test (OGTT) 48hours before the end of the 13-week study. Thereafter, the rats were euthanazed at term (age -13 weeks old) for visceral measurements; and blood levels of metabolic substrates, leptin, insulin, and hepatic storage of glycogen and lipids were also obtained.

\section{Results}

NH significantly $(\mathrm{p}<0.01)$ increased total body weight (TBW), than the other diets. GS increased circulating

1Department of Physiology, Faculty of Basic Medical Sciences, Olabisi

Onabanjo University, Ikenne 121002, Ogun State, Nigeria

Full list of author information is available at the end of the article fasting glucose, triglycerides and free fatty acids $(\mathrm{p}<0.05)$. Contrary to the GS-fed rats, the NH-fed animals showed tolerance to an oral glucose load. Golden syrup also significantly increased $(\mathrm{p}<0.001)$ visceral fat weight, and caused hepatomegaly unlike $\mathrm{NH}$. There were also hypercholesterolemia, hyperinsulinemia and increased hepatic fat stores in the GS-fed rats relative to $\mathrm{NH}$ groups. The difference in the hepatic glycogen content between the GS and $\mathrm{NH}$ fed rats did not attain any significance at both doses. The area under the curves (AUC) calculated from the OGTT results showed the tendency of our GS-fed rats to hyperglycemia, while the $\mathrm{NH}$-fed rats were normoglycemic. The increased levels of metabolic substrates and visceral fat weight were not observed in the $\mathrm{NH}$-fed rats.

\section{Conclusion}

$\mathrm{NH}$ induced healthy growth in rats as previously observed [4], due to its several micronutrients, antioxidants and phytochemical constituents $[5,6]$. The rats fed GS diets for 13 weeks were predisposed to developing diet-induced MetS. Unlike GS, feeding rats $\mathrm{NH}$ from an early age did not cause susceptibility to MetS. NH is a healthy source of dietary sugars, as the rats were not predisposed to dietary-induced MetS [7]. This suggested potential nutritional benefits of substituting honey for refined sugars in animal feed and by extension human diet.

\section{Author details}

${ }^{1}$ Department of Physiology, Faculty of Basic Medical Sciences, Olabisi Onabanjo University, Ikenne 121002, Ogun State, Nigeria. ${ }^{2}$ School of Physiology, Faculty of Health Sciences, University of the Witwatersrand, 7 York Road, Parktown 2193, South Africa. ${ }^{3}$ Department of Veterinary Anatomy and Physiology, Faculty of Veterinary Science, University of Pretoria, Onderstepoort, South Africa. 


\section{References}

1. Johnson RJ, Segal MS, Sautin Y, Nakagawa T, Feig DI, Kang D, et al: Potential role of sugar (fructose) in the epidemic of hypertension, obesity and the metabolic syndrome, diabetes, kidney disease, and cardiovascular disease. Am J Clin Nutr 2007, 86(4):899-906.

2. Ford ES, Giles WH: A comparison of the prevalence of the metabolic syndrome using two proposed definitions. Diabetes Care 2003, 26:575-581.

3. Cruz ML, Goran Ml: The metabolic syndrome in children and adolescents. Curr Diab Rep 2004, 4:53-62.

4. Ajibola A, Idowu GO, Amballi $\mathrm{AA}$, Oyefuga $\mathrm{OH}$, lquot IS: Improvement of some haematological parameters in albino rats with pure natural honey. J Biol Sci Res 2007, 2:67-69.

5. White JW, Doner LW: Honey composition and properties: beekeeping in the United States. Agric Handbook 1980, 335:82-91.

6. Schramm DD, Karim M, Schrader HR, Holt RR, Cardetti M, Keen CL: Honey with high levels of antioxidants can provide protection to healthy human subjects. J Agric Food Chem 2003, 51:1732-1735.

7. Busserolles J, Gueux E, Rock E, Mazur A, Rayssiquier Y: Substituting honey for refined carbohydrates protects rats from hypertriglyceridemic and prooxidative effects of fructose. J Nutr 2002, 132(11):3379-3382.

doi:10.1186/1753-6561-6-S3-P3

Cite this article as: Ajibola et al:: Long-term dietary supplementation with natural honey does not predispose growing male rats to metabolic syndrome. BMC Proceedings 2012 6(Suppl 3):P3.

\section{Submit your next manuscript to BioMed Central} and take full advantage of:

- Convenient online submission

- Thorough peer review

- No space constraints or color figure charges

- Immediate publication on acceptance

- Inclusion in PubMed, CAS, Scopus and Google Scholar

- Research which is freely available for redistribution

Submit your manuscript at www.biomedcentral.com/submit 